\title{
On Spreading and Controlling of Online Rumors in We-media Era
}

\author{
Jia Liang ${ }^{1} \&$ Min Yang ${ }^{1}$ \\ ${ }^{1}$ School of Journalism and Communication, China West Normal University, Nanchong, China \\ Correspondence: Min Yang, School of Journalism and Communication, China West Normal University, \\ Nanchong, China. E-mail: cwnuyangmin@qq.com
}

$\begin{array}{lc}\text { Received: January 21, } 2015 & \text { Accepted: February 12, } 2015 \quad \text { Online Published: April 21, } 2015 \\ \text { doi:10.5539/ach.v7n2p42 } & \text { URL: http://dx.doi.org/10.5539/ach.v7n2p42 }\end{array}$

\begin{abstract}
Sufficient conditions have been provided for the emergence and development of us media due to the mature of network technology. Frequently, incidents of online vicious rumors take places in we-media environment with features of linkage anonymity, immediacy and convenience both online and offline, along with the wide-spread influences and severe harm. Nowadays, Internet rumors have become not only a major issue which needs to be paid great attention to in the field of information dissemination, but also a key factor affecting China's social stability and economic development. It's urgent to study the spreading mechanism of Internet rumors and to control it.
\end{abstract}

Keywords: we-media, Internet rumors, propagation mechanisms

Media is used by ordinary people who want to share his or her experiences and ideas on BBS forum, SNS social networks, micro-blog, we-chat, instant messaging and so on. They are the era of media of our own voices instead of traditional and intermediate media. The production right, editing, and communicating of information will be handed to all Internet users, everyone owns the media, everyone is a communication subject, and also the audience. People attract concerns from the upper class by communicating and interaction with governments, news agencies, opinion leaders and so on through these media facilities.

\section{Internet Rumors in We-Media Era}

With the development of society and economy, the public participation of social management increases, more and more emphasis is paid to people's opinions by community managers. People's public opinions are the bases of effective social public decision-making, as the saying goes "the water can carry a ship but also upset it", people oriented, comply with the public opinions of social management is the foundation of national stability. Internet is the most widely used and the most concentrated channels by social managers to listen to public opinions. However, due to its fast spreading, wide range and difficult to examine and such characteristics lead to a mixture of network information. It allows the rumors to swoop in and spreading in the micro-blogs and other new communication platforms quickly to form a contagion in the crowd, c even serious social mass events may be caused when some rumors in the dissemination process mixed with some irrational factors. It is easy to sharpen conflicts and even serious mass events may be caused when some rumors are mixed with some irrational factors in the dissemination process. So the Internet rumors are negative public opinion phenomena that could not be ignored.

Rumors exist in human society since ancient times (Lou \& Li, 2012). Long before the appearance of characters, information was taught orally in the crowd, in the process, the inconsistency with the facts is the rumor. But Internet rumors are of many differences with rumors in traditional society. Internet rumors are generated and spread through the Internet media. The main types of typical Internet rumors that have appeared in recent years include the political rumors, emergency rumors, economical rumors and public figure rumors.

Rumor has the characteristics of psychological manipulation (Gustavo \& Feng, 2007). Le Pen held the opinion that "Emotions and minds of gathered crowds all take the same direction; their conscious personality disappeared and formed a collective psychology". People who gather in groups for a long time are easily to accept psychological suggestions, which allow ideas to become contagious among groups with each other and externalize ideas and emotions into group behavior. Rumors can guide the thoughts and feelings of a group of members to have a certain attitude towards the event and promote the development of the situation. The mass emergence of rumors is precise because they are related to the interests and needs of certain groups, almost all the rumors and all social realities have certain correspondences, which are people's anxieties and fears for real life and a refraction of 
dissatisfactory of their demands for the society and reality. People's affirmation about the content of rumors is the premise of the spread of rumors, which is the premise of turning gossips into rumors and the basis of effectiveness of follow up spreading of rumors.

\section{The Reasons of the Formation of Rumors}

Harmful rumors with severe impacts are kinds of rumors that may be repeatedly mentioned afterwards, for example the rumor " one HIV patient from Xinjiang spreads AIDS by dropping infectious blood into objects, " will remain quiet for a while and reappear after being disposed, another kinds of rumors are rumors that are confirmed to be harmless in the dissemination process. It is harmful rumors that needed to be attached to great concerns and controlled by social managers undoubtedly. But the definition of the nature of rumors request us to dig out the reasons of formation of Internet rumors: rumor mongers, propagators and receivers.

Large amounts of rumors tend to appear in crisis or dramatic social changes. From the rumor "The Chu is reviving, Chen sheng will be king" (Qian, 104 B.C) in the Qin and Han Dynasty, to other rumors in Tai ping Rebellion and Revolution and other revolutions in the early modern times, it has be proven that nearly all rumors will emerge in each social change. The more the stimulating factors are, the wider the rumors may influence. At present, in China, Internet rumor -prone situation is all related to the international and domestic environment, the changes in people's psychology, the natural environment and so on.

(1) The awakening of civic consciousness and lack of official information. American sociologists think that rumors always originate from important and complicated events (Noel \& Ferer, 2008). The existence of information black holes is the reason of the appearance of rumors. The rumors then start the process of transmission under the guidance of a few people and the blind obedience of one section of people in the background of opaque information. The more important the event itself is, and the more inadequate the information publicity is, the more fully the rumors may spread.

The emergence of the rumors is also a reflection of public opinion. Although Internet rumors are negative, we, however, still can get the information about people's concerns, appeal, fear and anger. Therefore, the appearance and transmission of rumors are due to the awakening of consciousness of civic engagement for social management. The invention of new media has achieved people's right to know and discourse power and their enthusiasm and initiative of participating social events increases. In the environment of highly freedom of the new media, most people will seek for so-called truth from strangers on Internet, once the government and official media are in slow response or keep cold treatment while people are eager to acquire more information and truth but can't get it by regular way. Some people even will make "reasonable" conjecture according to the information that is gotten by themselves. All of these things will create an adverse situation before the event is to be duly handled. Take "Li Zhuo micro-blog event" for instance. On April 12 $2^{\text {th }}, 2014$ @ Li Zhuo19961003 posted a statement muckraking latent rules like rebates in officialdom. The numerous users believed the news and shared it. Although, it was confirmed by network managers in Chengdu to be a rumor, it still caused trouble and trauma to Li Zhuo and his family. People's malicious conjecture about bad custom in officialdom was difficult to be eliminated.

(2) The uncertainty of transformation period. Our country is in the process of social transformation. The change in the format of interest pattern brings the prominent social contradictions, and the uncertainty of the political and economic environment causes the people's confusion and fickleness towards the future, and further negative emotions like envy, distrust and dissatisfaction. In July 2010, the real estate commentator Niu Dao claimed in his blog: According to Refrigerators news, there were 65.4 million vacant suites, 12.5 million apartments are under construction, if three people live per suite, there will be available for 260 million populations.

After the release of news, great attention has been aroused by the media and Internet users, rampant criticism appeared on public policy and regulation of real estate property bubble. This data was then proved to be unfounded. But the incident still reflects people still attaches importance to housing problem and also reflects people's dissatisfaction towards the high prices, excessive investment of housing.

(3) Frequent public safety incidents have occurred .It is because the drive of economic interests in recent years, the public safety events like public life, food, and personal safety has occurred frequently. People can easily form a sense of suspicion and mistrust through tainted milk, leather capsules, school bus accidents and other safety incidents. A little bit of trouble can ignite fear of people. For example, it is said that there was a restaurants which cook rice noodles with corpse oil. The news was has been circulated crazily since it came out, people rebuked that" there's nothing safe to eat." But afterwards the Food Safety Commission and Drug Administration has found no proof of abnormality in edible oil; Guangxi Politics and Law Committee also said that the public security authorities have never received a report in this case (CATV, 2011). We can know that the passing rumor was 
completely non-existent. But most people held the attitude of "preferring to believe them" towards the event, and a lot of people decided not to eat rice noodle anymore.

(4) Psychological trauma caused by the extreme and unexpected incidents. During the process of social transformation, local governments will inevitably be tough in the means of dealing with the relationships between government and people, the rich and the poor, officials and businessmen in order to ensure economic development and maintain social stability. It may lead to a variety of tensions of social relations, Some extreme emergencies, and even the growing conflicts. At the same time, it may also lead to distrust to the existing social order. A piece of micro blog, as long as it includes some negative information about officials and governments, it will be easy to be concerned and spread. Ordinary car accidents do not cause the crowd's attention, however, if the perpetrator is a affluent second generation or an official ling, it will make a lot of Internet users rush to attack; the rumor " Cheng guan hit people" is always on the top topic list. People classified themselves as vulnerable group, and law executors are" hostile power". When the two parties clash with each other, it will quickly gather hatred, which are the emotional reasons of Internet rumors about official corruption, income disparity to be spread fastest and most widely.

(5) Their desires for the information lead to the trust of the rumor. Information on the Internet is multifarious, It needs internet user to identify. Today there are a lot of rumors which are disguised by science, but people have never thought of distinguish fact from fiction when they receive the information. Whenever an infectious disease appear or incidents involved health happen, for example, no matter it is true or false, the wave of panic buying may happen among people. And resistance of the PX project and the recent debate about genetically modified foods are warning we should attach great importance to science. To helping cultivate public habit of acquiring scientific knowledge and scientific thinking is essential to enhance China's soft power.

Owing to lack of social credibility, the anomie of traditional media, and the environment of bad commercial interests, Internet rumors can also be formed.

\section{The Controlling of Internet Rumors Spreading}

Complete network rumor spreads usually through three processes, the formation of rumors, the climax of spreading and the recession of events. In the process, because of the media itself characteristic, Internet rumors may be reposted and be modified several times. When Internet rumors are reinvented re-invention, content may be extracted or changed because of creator's own interest, characteristics and values. So Internet rumors may include "interpret out of context". Such network rumors are intercepted one or a few words from the original information and presents different meanings. As the "Lü commentaries of history" for "wear well gadites" example: There is a story called "Chuan Jing De Ren" in Lü commentaries of history (Xu, 2009). In Song country, a family surnamed Ding had to fetch water somewhere far away from their house, for no well to use. It was because of the condition, they always let a family member go out and fetch water. After getting their own well, they told people that they got a person when they dug well. From then on, the news were know by more and more people, and finally, the king of Song country got the news and ordered a person to ask the family whether it was true or not. Without any doubt, it was unreal, the family explained that they would no longer let a family member to fetch water after digging well, and it is equivalent to saving a labor force, in other words, they got a person.

We-media usually forms and spreads rumors with these features: 1). Launch news on we-media homepage in public bar. Between groups of general rumors spreading, it is difficult to cause the spreading of mass. But we-media rumors spread by we-media share characteristics, and can make people do not know and also see other's speech, which makes the spreading of rumors become faster and more widely. 2). We-media rumors spread out radically. Traditional rumors spread from person to person, namely the point-to-point transmission, due to the micro blogging forwarding function, people make the information sharing realized, and then the information stacks repeatedly, and spreads radically. 3). The authenticated user big V and the spreading of "opinion leaders". We-media has some was officially certified public identity, as well as has news sensitivity, they can get access to information resources much more easily than normal people. So they are more likely to influence the majority of users in we-media, and exert their influence in the dissemination of information. As a result, personal opinions of some big V and "opinion leaders", or the false information will not be checked; it is easy to gather them into people's attitudes. "Opinion leaders" manipulate the internet users, rumors spread wantonly, and imaginations also happen from time to tome (Sheng, 2013).

Throughout Chinese history, although the ancient China nearly didn't have free speech and the information circulation was poor, rumors emerged in endlessly, quietly guided non-governmental public opinion. Although to some extent, inciting conditions of people is for use of specific interest groups, we can't deny that rumors of passion can make people gather a lot of destructive powers in a very short period, so all previous dynasties rulers 
attached too much importance to listening to people, controlling the spreading of the rumors. Caring about what people think, knowing folkways, listening to the ballad are a major of means that ancient Chinese rulers adopted to pay close attention to public opinion; Politicians and thinkers pay much attention to making progress of ancient people's minds, "people can be bright, also can not be foolish", so the ruler also comply with the idea of deepening people's ideological cultivation; Under the autocratic monarchy system, the main means that rulers use to curb rumors are criminal law, according to the actual circumstances of the rumors spreading, rulers may pass different sentences on manufacturer or distributor (Zhou, 2012). Summarizing historical experiences, why an ancient Chinese rulers can recruit the Magi, tolerate his faults, and nip that in the bud, there are two mains " Rumor stops at those who are witty " and " if a king is wise, his people will not believe any rumors". Improving people's ideological and moral cultivation, improving the ability of distinguishing rumors, rumors can be stopped by a wise man; its transmission process will be smoothly terminated independently. If Authorities pay attention to extracting the public opinion, improving its administration capability; and officials are clean, people will not be confused. How ancient kings controlled the rumors also have great enlightenments to controlling today's network rumors.

(1) Improve citizens' moral quality, strengthen the rational thinking, and enhance the ability of telling information. The dangers of Internet rumors are very big, the internet user are the main part of the network public opinion, the Internet rumors spreading is not only the online activities of people, but also will seriously affect the users' real life, and even disrupt normal psychological activities of the Internet users, it may change people's political positions, affect people's social behaviors, lead to fierce social conflicts, cause serious social chaos, and threaten social stability. Therefore, in social life, we must strengthen citizen's ideological and moral construction, adhere to the core socialist values, firm ideal, and love the motherland, no matter how fierce the contradictions against the domestic affairs are, we should still defend nation's collective interests. At the same time, we should learn things consciously enhance the rational thinking, improve the ability of distinguishing the information, and become a rational internet user.

(2) Improve the service quality of media practitioners. Media play the role of speaking true information, we must always check on strictly, strengthen the audit and the release management, the news media professionals should strengthen their business training and professional ethics, and be strict with the authenticity and objectivity of news sources, insist on offering the truths at any time to ensure a correct understanding of the facts strengthen the information disclosure transparency.

(3) Social management system is not perfect, which is the root cause of the frequent happening of political Internet rumors, making efforts to improve the system of social management, and to make all aspects of social management be in accordance with laws, can minimize social contradictions in the process of social management. Managers should enhance information transparency, release real information in time, guarantee citizens' right to know, provide people with formal access to public information, rather than block the information, and conceal the conditions when facing emergencies,. Meanwhile, the governors should destroy the soil of rumor and let the information disclosure be faster than the spreading of rumors. Government and people should work together to form barriers against rumors, and let the rumors disappear in the sun.

(4) Perfect laws and regulations system; establish strict accountability system of network transmission. Laws and regulations are the most basic forms of code of conduct. We should do the following: Clear all the legal responsibility of Internet rumors spreading, improve the system of legal responsibility, and make the maker of Internet rumors, discriminator all have to undertake the responsibility, instead of using the Internet to escape. Implementing network real-name registration system, and doing this step by step is also an important part of network law enforcement.

(5) Strengthen the internet technology to control and manage the transmission. The Internet, after all, is a technology platform, in addition to the control of the social environment and participation main body. The technological developments of network technology are also an important means to control the rumor. At present, there are technical difficulties in Internet rumors regulation, but we can take advantage of the existing means to track the origin of Internet rumors effectively and to warn and control him or her, a warning shall be issued or controlled. We can also rely on technology to comb the network information, and achieve the effective early warning of Internet rumors.

(6) Control the rumors. Controlling only can achieve restraint effect on the spreading of Internet rumors, but it does not eliminate its adverse effects. In order to make the network of rumors in the network thoroughly be cleaned. We should not only recognize rumors, but also points out that the rumor is false, and let people see the crux of the rumors. Here we should attach great importance to the effects of government micro-blogging, to the official voice, and guide the direction of public opinion. 
(7) The establishment of public opinion supervision system. The processing mode of the current Internet rumors mostly is to control them after their appearance, but not to advance prevention and early warning. So public opinion analysis agency should pay attention to the psychological state of the public in time, to know people's thinking trend, the recent attention and appeal of social public should be adjusted properly. Government should also find rumors as soon as possible to resolve the crisis, and use government micro blogging to make precautions. This is also an important way of social management maturity.

In the Internet supervision, technique is not perfect at present; the controlling of Internet rumors mainly depends on two big aspects:-people's self-awareness and reshaping the social credibility. With government efforts made to enhance social credibility, most of rumors will not exist, for the elimination of the advantageous environment; people should improve their ideological accomplishments. Using rational thinking can select information consciously, by which people may identify a rumor and curb the spread of rumors. What's worth mentioning is that the government should pay attention to adjusting the administration power, in case of arousing people's antipathy in the process of control of rumors.

\section{References}

CATV. (2011). Network transmission of a Rice noodles shop in Guangxi Hezhou with the corpse cooking oil powder Multi sectoralr esponse: not true. Retrieved August 25, 2011, from http://finance.ifeng.com/roll/ 20110825/4463639.shtml

Gustavo, L. B., \& Feng, K. L. (2007). A motley crew-a study of the popular mind. Guangxi Normal University Press.

Lou, X. D., \& Li, F. (2012). From the communication analysis of network rumor. Now the media, 7, 18-21.

Noel, J., \& Ferer, K. (2008). Rumors. Shanghai people's Press.

Qian, S. M. (104 B.C). Historical Records Chen She family. Historical Records, 58.

Sheng, H. J. (2013). Internet rumors coping with public opinion guide. Beijing: Social Sciences Academic Press.

Xu, W. Y. (2009). Lü commentaries of history notes. Beijing: Zhong Hua Press.

Zhou, Y. Q. (2012). Research on network rumors of contemporary Chinese Society. Beijing: Commercial Press.

\section{Copyrights}

Copyright for this article is retained by the author(s), with first publication rights granted to the journal.

This is an open-access article distributed under the terms and conditions of the Creative Commons Attribution license (http://creativecommons.org/licenses/by/3.0/). 